\title{
Nexus between Foreign Remittances and Economic Growth in Nigeria: Role of the Financial Sector
}

\section{Kassey P. Garba ${ }^{1}$ \\ Wasiu Adekunle ${ }^{2}$ Oluwatosin Adeniyi ${ }^{3}$}

'Professor at the Department of Economics, University of Ibadan, Nigeria. Email:kagarba@yahoo.com Tel: +2348095726890

${ }^{2}$ Research Analyst at The Nigerian Economic Summit Group (NESG), Lagos, Nigeria. Email:wasiu.adekunle@nesgroup.org.Tel:+2348176308263

${ }^{9}$ Senior Lecturer (Ph.D.) at the Department of Economics, University of Ibadan, Nigeria. Email:saino78@yahoo.com Tel:+2347033275062

\section{Abstract}

In recent times, the economic growth literature is becoming more interested in the macroeconomic impacts of foreign remittances. This focus could be because foreign remittances now constitute the largest source of foreign capital flows for developing countries next to foreign direct investment (FDI). To this end, the present study analyzed the possible role of the financial sector in the nexus between foreign remittances and economic growth in Nigeria over the period of 1981 to 2015. To circumvent the possible endogeneity problem among foreign remittances, financial development and economic growth, we employed the two-stage least squares (2SLS) technique. Unlike the previous findings, we offered new evidence that the complementarity or substitutability between foreign remittances and financial development in promoting Nigeria's economic growth depends on the indicators of financial development used. We confirmed the complementary hypothesis in the case of the quantitative indicators of financial development, while we validated the substitutability hypothesis in favour of its qualitative measure. Both migrant workers and their beneficiaries should be encouraged to make use of banks so that foreign remittances could be made available to finance genuine investments. This could be possibly achieved through boosting the confidence of migrant workers in the domestic financial system and by raising the deposit rate so as to entice the beneficiaries to save a large chunk of remittances received.

Keywords: Foreign remittances, Financial Sector, Economic growth, Complementarity, Substitutability, Two-stage least squares. JEL Classification: C26; E22; F21; O23

Citation | Kassey P. Garba; Wasiu Adekunle; Oluwatosin Adeniyi (2020). Nexus between Foreign Remittances and Economic Growth in Nigeria: Role of the Financial Sector. Asian Journal of Economics and Empirical Research, 7(1): 15-24. History:

Received: 14 November 2019

Revised: 18 December 2019

Accepted: 22 January 2020

Published: 24 February 2020

Licensed: This work is licensed under a Creative Commons

Attribution 3.0 License $(\mathrm{cc})$ E

Publisher: Asian Online Journal Publishing Group
Acknowledgement: All authors contributed to the conception and design of the study.

Funding: This study received no specific financial support

Competing Interests: The authors declare that they have no conflict of interests.

Transparency: The authors confirm that the manuscript is an honest, accurate, and transparent account of the study was reported; that no vital features of the study have been omitted; and that any discrepancies from the study as planned have been explained.

Ethical: This study follows all ethical practices during writing.

\section{Contents}

1. Introduction 16

2. Empirical Literature Review 17

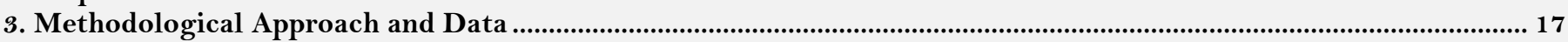

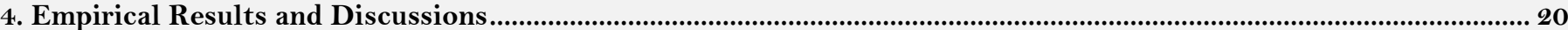

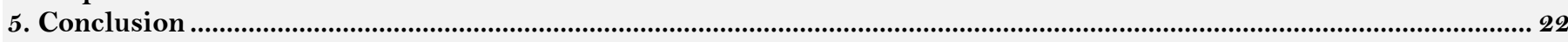

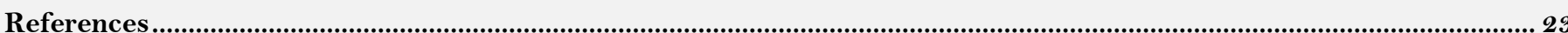




\section{Contribution of this paper to the literature:}

This study investigates whether the domestic financial sector and foreign remittances could be described as complements or substitutes in advancing economic growth in Nigeria.

\section{Introduction}

The growing debates over the sources of economic growth of developing countries have taken the centre-stage of the economics literature for more than half a century ago. ${ }^{1}$ The sources of economic growth that have been identified include labour force, physical capital investment, foreign capital flows, human capital, as well as, research and development $(\mathrm{R} \& \mathrm{D})$. Institutional factors ranging from political freedom, political instability to voice and accountability have also been argued to play key roles in the growth and development of a country (Fayissa and Nsiah, 2010). In recent times, the economic growth literature is becoming more interested in the macroeconomic impacts of foreign remittances. This focus could be because remittances now constitute the largest source of foreign capital flows for developing countries next to foreign direct investment (FDI) as it currently represents almost double foreign aid receipts of developing countries (see, for instance, (Giuliano and Ruiz-Arranz, 2009; Bettin and Zazzaro, 2011)).

There have been efforts made by past authors towards analyzing the possible linkage between remittances and economic growth through various channels including consumption, investment, financial sector, institutions, and human capital ${ }^{2}$. The first attempt to quantify the impact of foreign remittances on economic growth depending on the complementarity or substitutability between foreign remittances and financial sector development is attributed to Giuliano and Ruiz-Arranz (2009). According to the authors, since foreign remittances are largely spent on consumption, the spill-over effect on the long-term growth are more likely to be minimal.

Therefore, a possible linkage between remittances and growth is the level of financial development in the recipient country. Apart from easing the liquidity constraints and improving the access to credit for the migrant's relatives, remittance inflows, if effectively intermediated, should permit the funding of growth-enhancing projects by financially constrained entrepreneurs. This implies a complementary relationship between remittances and financial development in promoting growth (Bettin and Zazzaro, 2011). However, Giuliano and Ruiz-Arranz (2009) argued that foreign remittances could become a substitute for inefficient or nonexistent credit markets by allowing local entrepreneurs bypass the high transaction costs usually associated with collateral security requirement. Meanwhile, informal money transfers are attractive to many immigrants since they are easily accessible, do not require proof of identity, cheap to access, and are reliable as the migrant's friends and relatives are involved. This has the consequence of reducing drastically the portion of remittances intermediated via formal channels, majorly banks (Nyamongo et al., 2012).

In sub-Saharan Africa, Nigeria was the highest recipient of foreign remittances in 2009 followed by Sudan and Kenya. Nigeria received an average of $\$ 3.23$ billion per annum over the period of 1980 to 2009 (Nyamongo et al., 2012). This trend is indicative of the high level of emigration in Nigeria. The increasing number of emigrants are partly due to rising population size, as well as, political upheavals that have threatened the socio-economic stability of the country since independence (Nyamongo et al., 2012). Beyond these two factors, yet another important "push factor" has been economic migration, that is, the so-called search for greener pastures. Coincidentally, Nigeria's financial sector remains largely shallow and underdeveloped despite the various financial reforms that have been instituted over time, starting with the Structural Adjustment Programme (SAP) in July, 1986. In light of the aforementioned, the current study, therefore, makes an attempt to analyze the complementarity or substitutability between foreign remittances and financial development in economic growth with respect to Nigeria. Specifically, the two key questions addressed in this study are: (i) Do foreign remittances have a significant impact on growth in Nigeria? (ii) Does the financial sector development have a role to play in the linkage between remittances and growth?

Having acknowledged the existing literature on the current subject matter, this study offers the following innovations. First, it represents a pioneer attempt to investigate the role of the financial sector in the nexus between foreign remittances and economic growth in the Nigerian context ${ }^{4}$. Second, this study differs from previous studies by employing both quantitative and qualitative measures of financial development, which represent the volume and efficiency indicators of financial development (Oyinlola and Adedeji, 2017). Since official remittances flow into the country through banks, only banking development indicators would be employed. Third, to differ from the existing literature, this study resolves the possible endogeneity bias that might exist among remittances, finance and growth by employing an instrumental variable (IV) estimation technique known as the two-stage least squares. $^{5}$

The remainder of the study is structured as follows. Section two contains the empirical literature review. Methodological approach and data constitute the discussions in Section three. Section four discusses empirical results, while Section five concludes.

${ }^{1}$ See, for instance, Solow (1956), Cheneryand Strout, (1966), Romer (1986) and Lucas (1988) among others.

'See, for instance, Jongawanich (2007), Ramirez and Sharma, (2008), Barajas, Chami, Fullenkamp, Gapen and Montiel, (2009), Catrinescu,. Leon-Ledesma, Piracha and Quillin, (2009), Giuliano and Ruiz-Arranz, (2009), Bettin and Zazzaro, (2011), Nyamongo, Misati, Kipyegon and Ndirangu, (2012), Barguellil and Zaiem, (2013), Chia (2014), Tung (2015) and El Hama (2016) to mention a few.

${ }^{3}$ See Ogujiuba and Obiechina, (2011), Umejiaku (2011) and Ikeora, Igbodika and Andabai, (2016) for a review of financial sector reforms in Nigeria since 1986. ${ }^{4}$ For the Nigerian economy, there is a vast literature covering finance-growth nexus (see, for example, Adelakun (2010); Balago (2014), Dandume (2014), Ogwumike and Salisu, (2012), Adeniyi, Oyinlola, Omisakin and Egwaikhide, (2015) remittances-finance nexus (see, for example, Oke (2011), Kayode and Adeleye, (2016) and remittances-growth nexus (see, for example, Odionye and Emerole, (2015).

Adeleye, (2016) and remittances-growth nexus (see, for example, Odionye and Emerole, (2015).
${ }^{5}$ They include, among others, the studies by Adelakun (2010), Oke (2011), Motelle (2011), Balago (2014), Chia (2014), Odionye and Emerole, (2015) and Tung (2015). 


\section{Empirical Literature Review}

This section entails a review of four strands of the empirical literature concerning the direct and indirect relationships among foreign remittances, financial development and economic growth.

\subsection{Remittances-Finance Nexus}

Aggarwal et al. (2011) reported a positive impact of remittances on financial development in the case of 109 developing countries between 1975 and 2007. Other authors that have confirmed the positive linkage between remittances and financial development include (Chowdhury, 2011) for Bangladesh over the period of 1971 to 2008; Oke (2011) in the Nigerian context for the period of 1997 and 2009; Ojapinwa and Bashorun (2014) for 32 subSaharan African (SSA) countries between 1996 and 2010, and Shahzad et al. (2014) in the context of South Asia over the period of 1989 to 2011. In terms of causality between remittances and finance, there were mixed results. For instance, Chowdhury (2011) established unidirectional causality from remittances to financial development in the case of Bangladesh, whereas (Akkoyunlu, 2013) found no evidence of causality between remittances and finance for the Turkish economy.

\subsection{Finance-Growth Nexus}

Allen and Ndikumana (1998) found that liquid liabilities have a positive effect on growth, whereas less conclusive results were generated in favour of other indicators of financial development, namely, credit to private sector and credit by banks, in the case of SADC region between 1970 and 1996. Subsequently, a number of authors have established a positive impact of finance on growth irrespective of the indicators of financial development used. They include, among others, Adelakun (2010) for the Nigerian economy between 1980 and 2008; Agbélénko and Kibet (2015) for the WAEMU region between 1981 and 2010, and Oyinlola and Adedeji (2017) for 19 countries in sub-Saharan Africa over the period of 1999 to 2014. The literature also suggests unidirectional causality from financial development to growth (Examples include, Balago (2014) for the Nigerian economy and Agbélénko and Kibet (2015) in their study of the 9 Francophone West African countries).

\subsection{Remittances-Growth Nexus}

A number of studies have established a significant and positive impact of foreign remittances on economic growth irrespective of specifications used. For instance, Vargas-Silva et al. (2009) reported that remittances had a positive effect on real gross domestic product per capita growth in the case of 20 Asian countries between 1988 and 2007. Other studies that have confirmed the positive relationship between foreign remittances and economic growth include, among others, Ahortor and Adenutsi (2009) in the case of 31 small open economies across Africa, Latin America and the Caribbean between 1996 and 2006; Fayissa and Nsiah (2010) for 36 African counties over the period of 1980 to 2004; Odionye and Emerole (2015) in the Nigerian context for the period of 1981 to 2011, and Meyer and Shera (2017) for 6 high remittances receiving countries between 1999 and 2013.6 Similarly, Catrinescu et al. (2009) reported that remittances had positive and significant effects on growth across the specifications considered. However, Barajas et al. (2009) found no positive impact of remittances on long-term growth, and, as such, the authors established a negative relationship for 80 countries over the period of 1970 to 2004 .

\subsection{Remittances-Growth Nexus: The Role of Finance}

The literature is mixed about the potency of finance in enhancing or dampening the growth effects of remittances. For instance, some authors found that finance magnifies the role of remittances in promoting growth thereby lending empirical support to the complementarity hypothesis. For instance, Mundaca (2009) reported that remittances had significant positive impact on growth in the long run, while financial intermediation helped to magnify the growth effects of remittances in their study of 25 Latin American and the Caribbean (LAC) countries between 1970 and 2002. Other authors that have confirmed the complementarity hypothesis include, among others, Bettin and Zazzaro (2011) in the case of 66 developing countries between 1970 and 2005; Nyamongo et al. (2012) for 36 African countries over the period from 1980 to 2009; Chia (2014) for Malaysian economy for the period 1984 to 2013, and El Hama (2016) in relation to 12 MENA countries between 1984 and 2012.

However, other authors found remittances and finance as substitutes in promoting growth. For instance, Ramirez and Sharma (2008) revealed that although foreign remittances had a positive effect on economic growth, both remittances and financial development acted as substitutes in promoting growth. Other authors that have confirmed the substitutability hypothesis, include, Giuliano and Ruiz-Arranz (2009) which covered 100 developing countries within the period of 1975 to 2002, and Tung (2015) for the Vietnamese economy between 1996 and 2012.

In addition, a large quantum of the empirical literature reviewed above, with the exception of Bettin and Zazzaro (2011) and Oyinlola and Adedeji (2017) utilized only the quantitative measures of financial development. This study attempts to fill this gap. Similarly, endogeneity bias that could exist among foreign remittances, financial development and economic growth has not been properly resolved in previous country-specific studies. The present study would also address this important issue.

\section{Methodological Approach and Data}

In order to resolve the possible endogeneity bias among foreign remittances, financial development and economic growth, the study finds it appropriate to employ the two-stage least squares (2SLS) technique. This study follows the routine procedures involved in time-series analysis ranging from unit root test, cointegration test to model estimation and post-estimation tests. These steps and data issues are discussed in turn following model specification. 


\subsection{Model Specification}

The present study adapts the dynamic model of Giuliano and Ruiz-Arranz (2009) to analyze possible complementarity and/or substitutability linkage between foreign remittances and financial development in promoting Nigeria's economic growth.

The empirical model is stated as follows:

$$
\begin{aligned}
& L R G D P_{t}=\alpha_{0}+\alpha_{1} L R G D P_{t-1}+\alpha_{2} R E M I T_{t}+\alpha_{3} F D_{t}+\alpha_{4}\left(R E M I T_{t} * F D_{t}\right)+\varepsilon_{t} \\
& F D_{t}=\left(D_{E P O S I T}, L L T_{t}, P C R_{t}, S P R E A D_{t}\right)
\end{aligned}
$$

Equation 1 implies that economic growth is a function of foreign remittances and financial sector development. Equation 2 identifies four indicators of financial sector development; where, $L R G D P_{t}$ is the natural $\log$ of real gross domestic product in the current period, and $L R G D P_{t-1}$ is the natural $\log$ of real gross domestic product in the previous period, such that $t$ indicates time period; REMIT is the remittance inflows (\% of GDP); FD is a vector of quantitative and qualitative indicators of financial development. The quantitative indicators (which measure the volume of financial development) include bank deposit, \% of GDP (DEPOSIT), liquid liabilities, \% of GDP (LLT), and domestic credit to private sector, \% of GDP $(P C R)$, whereas the only qualitative indicator (which measures the efficiency of financial development) is interest rate spread (SPREAD), that is defined as the difference between lending rate and deposit rate. (REMIT $* F D)$ is a term involving the interaction between remittance inflows and indicators of financial development. It is included to capture the role of financial development in the relationship between foreign remittance inflows and economic growth. In this study, the control variables, including, gross fixed capital formation, government final consumption expenditure, and trade openness are used as part of the instruments to control for possible endogeneity problem, and they are not stated explicitly as part of the explanatory variables. While $\alpha_{1}, \alpha_{2}, \alpha_{3}, \alpha_{4}$ are regression coefficients, $\varepsilon$ is a stochastic disturbance term.

\subsection{A priori Expectations \\ $\alpha_{1}, \alpha_{2}, \alpha_{3}>$ or $<0$.}

If $\alpha_{4}>0$, then foreign remittance inflows and financial development have complementary role in promoting growth). If $\alpha_{4}<0$, then foreign remittance inflows and financial development are substitutes in promoting growth).

\subsection{Unit Root Tests}

\subsubsection{The ADF Unit Root Test}

Following Dickey and Fuller (1979) a random walk process may have no drift (or intercept), or it may have a drift, or it may have both deterministic and stochastic trends (Gujarati and Porter, 2009). To allow for these variants, Dickey and Fuller started by specifying the general test regression (the model that includes both the deterministic and stochastic trends), and then obtain the other two possibilities by restricting some parameters.

The general test regression is

$$
\Delta Y_{t}=\beta_{1}+\beta_{2} t+\delta Y_{t-1}+\varepsilon_{t}
$$

Equation 3 implies that $\mathrm{Y}_{\mathrm{t}}$ is a random walk with drift (or intercept) and deterministic time trend

Restricting $\beta_{2}=0$ gives

$$
\Delta Y_{t}=\beta_{1}+\delta Y_{t-1}+\varepsilon_{t}
$$

Equation 4 implies that $\mathrm{Y}_{\mathrm{t}}$ is a random walk with drift only

Also, restricting $\beta_{1}=\beta_{2}=0$ gives

$$
\Delta Y_{t}=\delta Y_{t-1}+\varepsilon_{t}
$$

Equation 5 implies that $\mathrm{Y}_{\mathrm{t}}$ is a random walk without drift and time trend

To take care of possible serial correlation in the errors $\left(\varepsilon_{t}\right)$, Dickey and Fuller developed another test called the augmented Dickey-Fuller $(A D F)$ test. This test augments the general Dickey-Fuller test regression above (that is, eq. 3) by including the lagged difference term(s) of the variable in question (in this case $\mathrm{Y}_{\mathrm{t}}$ ) and then restricting the intercept coefficient and the coefficient on time trend to zero to obtain the other possibilities.

The general test regression (that is, Equation 3) now becomes

$$
\Delta Y_{t}=\beta_{1}+\beta_{2} t+\delta Y_{t-1}+\sum_{i=1}^{m} \alpha_{i} \Delta Y_{t-i}+\varepsilon_{t}
$$

Equation 6 augments Equation 3 above with the lagged difference terms of $Y_{t}$ so as to correct for possible serial correlation inherent in the variable $\mathrm{Y}_{\mathrm{t}}$. The number of lagged difference terms (in this case $m$ ) included in the test regression can be determined using information criteria, such as, Schwartz information criterion (SIC) and Akaike information criterion (AIC) until the errors become white noise (that is, the errors having constant mean and variance, and being uncorrelated with one another).

The null and the alternative hypotheses being tested are, respectively

$$
\begin{gathered}
\mathrm{H}_{0}: \delta=\mathrm{O}(\mathrm{Y} \text { is non-stationary or contains a unit root) } \\
\mathrm{H}_{1}: \delta<\mathrm{O} \text { (Y is stationary or does not contain a unit root) }
\end{gathered}
$$
former.

The rejection of Equation 7 implies that Equation 8 is valid, otherwise we will not reject the validity of the

The null hypothesis is tested against its alternative using the conventional t-ratio for $\delta$, stated as

$$
t_{\delta}=\hat{\delta} / \operatorname{se}(\hat{\delta}) \text {. }
$$

Equation 9 is the student's $t$ statistic which is computed as the ratio of the estimated coefficient to its standard error. 


\subsubsection{The Phillips-Perron (PP) Test}

Phillips and Perron (1988) proposed an alternative (nonparametric) method of controlling for serial correlation when testing for a unit root. The PP method estimates the non-augmented DF test equation (that is, Equation 3), and then modifies the t-ratio of the autoregressive coefficient $\delta$ so that serial correlation does not affect the asymptotic distribution of the test statistic. The PP test is based on the test statistic stated as

$$
\widehat{t_{\delta}}=t_{\delta}\left(\frac{\gamma_{0}}{f_{0}}\right)^{1 / 2}-\frac{T\left(f_{0}-\gamma_{0}\right)(s e(\widehat{\delta}))}{2 f_{0}^{1 / 2} s}
$$

Equation 10 is the modified t-ratio which is the difference between the unadjusted t-ratio (as in Equation 9) and the second term $\left[\frac{T\left(f_{0}-\gamma_{0}\right)(s e(\widehat{\delta}))}{2 f_{0}^{1 / 2} s}\right]$ that accounts for possible serial correlation; an approach that can be described as non-parametric, unlike the ADF test which adopts a parametric approach, represented by the fourth term in Equation 6 above. $\hat{\delta}$ is the estimated autoregressive coefficient, $t_{\delta}$ is the t-ratio of $\delta, s e(\hat{\delta})$ is the coefficient standard error, and $s$ is the standard error of the test regression. Also, $\gamma_{0}$ is a consistent estimate of the error variance calculated as $(T-k) s^{2} / T$, where $k$ is the number of regressors, while $f_{0}$ is an estimator of the residual spectrum at frequency zero.

\subsection{The ARDL Bounds Cointegration Test}

Traditional approaches to testing for the existence of long-run relationships, such as, Engle-Granger and Johansen cointegration methods require all variables to be strictly I(1). In order to accommodate variables with different orders of integration, Pesaran et al. (2001) developed the autoregressive distributed lag (ARDL) model. It has the advantage that variables in a cointegrating relationship can be either I(O), I(1) or a combination of both. An autoregressive distributed lag (ARDL) is a least squares regression that contains lags of the dependent variable (called the autoregressive terms) and of the explanatory variable(s) (called the distributed lag terms). ARDL models are usually denoted in notational terms as $\operatorname{ARDL}\left(p, q_{1}, \ldots, q_{K}\right)$, where $p$ is the number of lags for the dependent variable, $q_{1}$ is the number of lags for the first explanatory variable, $q_{K}$ is the number of lags of the $K^{\text {th }}$ explanatory variable, and $K$ is the number of explanatory variables $\left(X_{1}, \ldots, X_{k}\right)$. For simplicity sake, this study adopts the ARDL $(1,1)$ subsequently.

Following Pesaran et al. (2001) the general ARDL specification is:

$$
\operatorname{ARDL}\left(p, q_{1}, \ldots, q_{K}\right): \quad y_{t}=\alpha+\sum_{i=1}^{p} \gamma_{i} y_{t-i}+\sum_{j=1}^{K} \sum_{i=0}^{q_{j}} X_{j, t-i}{ }^{\prime} \beta_{j, i}+\epsilon_{t}
$$

Equation 11 is an ARDL model which include $p$ number of lags for the dependent variable $(y)$ and $q$ number of lags for the independent variables $(X)$; while the minimum number of lags for the former is one, that of the latter is zero.

In the current case, we will consider $\operatorname{ARDL}(1,1)$, where $p=1, K=1$ and $q_{k}$ where $k \in(0,1)$

$$
\operatorname{ARDL}(1,1): \quad y_{t}=\alpha+\gamma y_{t-1}+\beta_{0} X_{t}+\beta_{1} X_{t-1}+\epsilon_{t}
$$

Equation 12 is an autoregressive distributed lag model with one lag term for each of the dependent and independent variables.

$$
\Delta y_{t}=y_{t}-y_{t-1} \text { and } \Delta X_{t}=X_{t}-X_{t-1}
$$

Equation $13^{\text {a }}$ implies that the first order difference of a variable is the difference between its values in two adjacent time periods.

$$
y_{t}=\Delta y_{t}+y_{t-1} \text { and } X_{t}=\Delta X_{t}+X_{t-1}
$$

Equation $13^{\mathrm{b}}$ is an alternative way of expressing Equation $13^{\mathrm{a}}$

Substitute for $y$ and $X$ in Equation 12 gives.

$$
\Delta y_{t}+y_{t-1}=\alpha+\gamma y_{t-1}+\beta_{0}\left(\Delta X_{t}+X_{t-1}\right)+\beta_{1} X_{t-1}+\epsilon_{\mathrm{t}}
$$

Collect like terms and express $y$ as a function of $X$ in difference form:

$$
\begin{array}{r}
\Delta y_{t}=\alpha+\gamma y_{t-1}-y_{t-1}+\beta_{0} \Delta X_{t}+\beta_{0} X_{t-1}+\beta_{1} X_{t-1}+\epsilon_{t} \\
\Delta y_{t}=\alpha+(\gamma-1) y_{t-1}+\beta_{0} \Delta X_{t}+\left(\beta_{0}+\beta_{1}\right) X_{t-1}+\epsilon_{t} \\
\Delta y_{t}=\alpha+(\gamma-1) y_{t-1}+\left(\beta_{0}+\beta_{1}\right) X_{t-1}+\beta_{0} \Delta X_{t}+\epsilon_{t}
\end{array}
$$

Equation 15 is the basic error correction model, with the first three terms constituting the error correction term (ECT), in line with the specification of the initial originators of the ARDL model (that is, Pesaran et al. (2001)).

Equation 15 can be re-written as:

$$
\Delta y_{t}=\alpha+(\gamma-1)\left[y_{t-1}-\left(\frac{-\beta_{0}-\beta_{1}}{\gamma-1}\right) X_{t-1}\right]+\beta_{0} \Delta X_{t}+\epsilon_{t}
$$

Equation 16 is an alternative way of expressing Equation 15 by factoring out the term $(\gamma-1)$.

$$
\text { By letting } \theta=\frac{-\beta_{0}-\beta_{1}}{\gamma-1}
$$

Equation 17 shows a composite parameter that involves three other parameters $\left(\beta_{0}, \beta_{1}\right.$ and $\left.\gamma\right)$

Replacing Equation 17 in Equation 16, the error correction model version of Equation 12 becomes

$$
\Delta y_{t}=\alpha+(\gamma-1) E C T+\beta_{0} \Delta X_{t}+\epsilon_{t}
$$

Equation 18 is the abridged version of Equation 15, where

$$
E C T=y_{t-1}-\theta X_{t-1}
$$

Equation 19 shows that the error correction term is the residual (or estimated error term) that is generated from the long-run segment of the ARDL model that relates $y$ with $X$ [since Equation 19 can be re-written as $\left.y_{t-1}=\theta X_{t-1}+E C T\right]$; where ECT is the error correction term and its coefficient $(\gamma-1)$ is the rate of adjustment of the dependent variable from its short-run disequilibrium to its long-run equilibrium value following a shock to the 
explanatory variable at period $(t-1)$ which is now corrected at period $t$. The a priori expectation is that the coefficient is expected to be negative and statistically significant for $y$ and $X$ to be cointegrated.

The null and the alternative hypotheses are:

$\mathrm{H}_{\mathrm{o}}: \gamma-1=0$ (There is no cointegration or no long-run relationship between $y_{t}$ and $X_{t}$ ). (20)

$\mathrm{H}_{1}: \gamma-1 \neq \mathrm{O}$ (There is cointegration or long-run relationship between $y_{t}$ and $X_{t}$ ).

\subsection{The Two-Stage Least Squares Technique}

One of the assumptions of the classical linear regression model (CLRM) states that the error term of an equation should be uncorrelated with each of the explanatory variables in the equation. If such a correlation exists, then the ordinary least squares (OLS) regression is biased. To avoid what is called "simultaneity bias", alternative estimation techniques would be explored depending on whether or not an equation in the system of equations is exactly identified or is overidentified. In general, in cases of exact identification, the appropriate technique is the method of "indirect least squares (ILS)", while in cases of overidentified equations, the "two-stage least squares (2SLS)" method is the most commonly used (Asteriou and Hall, 2007).

Following Gujarati and Porter (2009) the two-stage least squares (2SLS) method is usually preferred over the indirect least squares (ILS) method for the following reasons:

(1) The 2SLS can be applied to an individual equation in the system without directly taking into account any other equation(s) in the system. Hence, for solving econometric models involving a large number of equation, 2SLS offers an economical method.

(2) Unlike ILS, which provides multiple estimates of parameters in the overidentified equations, 2SLS provides only one estimate per parameter.

(3) Although specially designed to handle overidentified equations, the 2SLS method can also be applied to exactly identified equations. In this case, ILS and 2SLS will give identical estimates.

Owing to the reasons stated above, the two-stage least squares (2SLS) technique is employed in this study. The estimation procedure involves two stages as follows:

Stage 1: Regress each endogenous variable (say, $Y$ ) which is a regressor as well, on all of the endogenous and lagged endogenous variables in the entire system by using simple OLS and obtain the fitted values of the endogenous variables of these regressions;

Stage 2: Use the fitted values from values from stage 1 as proxies or instruments for the endogenous regressors in the original (structural form) equations.

The instruments are variables that are stochastic and independently distributed of the error term. One requirement is that the coefficients of determination (R-squared) of the estimated equations in stage 1 should be relatively high. This is in order to ensure that the fitted $Y$ (that is, $\hat{Y}$ ) and the actual $Y$ are highly correlated so as to justify $\hat{Y}$ as a good instrument for $Y$ (Asteriou and Hall, 2007).

\subsection{Data Scope and Sources}

The present study employs annual data series on the Nigerian economy covering the period from 1981 to 2015 collected from different sources. The data on real gross domestic product, gross fixed capital formation, government final consumption expenditure, trade openness, and interest rate spread were obtained from the World Bank's (Word Development Indicators (WDI), 2017) whereas the data on remittance inflows and other financial development indicators (bank deposits, liquid liabilities, and domestic credit to private sector, all expressed as percentages of GDP) were collected from the financial structure dataset as updated by Beck et al. (2015) in September, 2015.

\section{Empirical Results and Discussions}

Here, the results of empirical analysis ranging from preliminary analysis (covering descriptive statistics, unit root test and cointegration test) to regression results are reported.

\subsection{Preliminary Analysis}

\subsubsection{Descriptive Statistics}

Table 1 presents the summary statistics on the main variables used in this study over the period of 1981 to 2015. The average value of real GDP is N210 billion. Other variables including remittance inflows (\%), bank deposits (\% of GDP), liquid liabilities (\% of GDP), domestic credit to private sector (\% of GDP), and interest rate spread have their respective means as $3.49 \%, 17.42 \%, 23.43 \%, 14.31 \%$, and 6.14 percentage points. The Nigerian financial sector is highly liquid with liquid liabilities having the highest mean value among the financial development indicators used. In terms of volatility as measured by the coefficient of variation of each variable, remittance inflows appear to be highly volatile with the highest coefficient of $105.59 \%$, whereas the least volatile series is liquid liabilities with the lowest coefficient of $28.89 \%$. In terms of the shape of the probability density of each variable as accounted for by Jarque-Bera statistic, liquid liabilities and interest rate spread are found to follow normal distribution, while other variables do not.

Table-1. Summary of descriptive statistics

\begin{tabular}{c|c|c|c|c|c}
\hline Variable & Obs. & Mean/Average & Standard Deviation & Coefficient of Variation (\%) & Jarque-Bera stat \\
\hline$R G D P$ & 35 & $210,000,000,000$ & $115,000,000,000$ & 54.7619 & $6.0362[0.0489]$ \\
\hline$R E M I T$ & 35 & 3.4982 & 3.6938 & 105.5914 & $7.7679[0.0206]$ \\
\hline$D E P O S I T$ & 35 & 17.4153 & 5.4808 & 31.4712 & $7.5431[0.0230]$ \\
\hline$L L T$ & 35 & 23.4278 & 6.7696 & 28.8956 & $3.9569[0.1383]$ \\
\hline$P C R$ & 35 & 14.3137 & 5.3519 & 37.3901 & $95.889[0.0000]$ \\
\hline$S P R E A D$ & 35 & 6.1416 & 2.8549 & 46.4846 & $1.6958[0.4283]$ \\
\hline
\end{tabular}


The non-normality of the majority of the series is an indication of the increasing variance of each variable over time. There is, therefore, the need to examine the unit root and cointegration properties in the variables so as to avoid the estimation of a spurious regression in the final analysis. The subsequent sections are devoted to addressing these issues one after the other.

\subsubsection{Results of Unit Root Tests}

The results of ADF and Phillips-Perron unit root tests are self-reinforcing (see Table 2). It is observed that only test regressions that are close to rejecting the null hypothesis of nonstationarity are reported. Accordingly, while domestic credit to private credit appears to be stationary at level and therefore requires no differencing, all other variables achieved stationarity after first differencing, and results are robust to the choice of unit root test approaches used.

\begin{tabular}{c|c|c|c|c|c}
\multicolumn{7}{c}{ Table-2. Results of unit root tests. } & Order of integration \\
\hline Variable & ADF test & & Phillips-Perron test & & \\
\hline & Level & $1^{\text {st }}$ Difference & Level & $1^{\text {st }}$ Difference & $\mathrm{I}(1)$ \\
\hline$L R G D P$ & $-2.0679^{\mathrm{A}}$ & $-4.9122^{\mathrm{A} * * *}$ & $-2.0667^{\mathrm{A}}$ & $-4.8611^{\mathrm{A} * * *}$ & $\mathrm{I}(1)$ \\
\hline$R E M I T$ & $-2.5067^{\mathrm{A}}$ & $-6.1471^{\mathrm{A} * * *}$ & $-2.5721^{\mathrm{A}}$ & $-6.2969^{\mathrm{A} * * *}$ & $\mathrm{I}(1)$ \\
\hline$D E P O S I T$ & $-2.5019^{\mathrm{B}}$ & $-5.7185^{\mathrm{B} * * *}$ & $-2.4214^{\mathrm{B}}$ & $-6.9583^{\mathrm{B} * * *}$ & $\mathrm{I}(1)$ \\
\hline$L L T$ & $-2.6957^{\mathrm{A}}$ & $-5.9501^{\mathrm{A} * * *}$ & $-2.3236^{\mathrm{B}}$ & $-7.9462^{\mathrm{B} * * *}$ & $\mathrm{I}(0)$ \\
\hline$P C R$ & $-2.6367^{\mathrm{B} *}$ & $\ldots \ldots \ldots \ldots \ldots \ldots$ & $-2.6367^{\mathrm{B}} * \ldots \ldots \ldots \ldots$ & $\ldots \ldots \ldots \ldots \ldots$ \\
\hline$S P R E A D$ & $-2.6528^{\mathrm{A}}$ & $-5.9659^{\mathrm{A} * * *}$ & $-2.6348^{\mathrm{A}}$ & $-12.4971^{\mathrm{A} * * *}$ & $\mathrm{I}(1)$ \\
\hline
\end{tabular}

Note: ******, and * indicate the rejection of the null hypothesis of a unit root at $1 \%, 5 \%$ and $10 \%$ significant levels, respectively; $\mathrm{I}(\mathrm{d})$ is the order of integration and it refers to the number of differencing required for a series to become stationary; pimplies that a series that is stationary at levels and does not require reporting its first difference; Superscripts "A", "B" and "C" denote models with in tercept and trend, with intercept only and with none, respectively.

\subsubsection{Result of ARDL Bounds Test for Cointegration}

The Bounds cointegration test becomes appropriate for the reason that this study employed variables with different orders of integration, namely $\mathrm{I}(0)$ and $\mathrm{I}(1)$ series. Since four indicators of financial development are involved, results of cointegration test based on a total of four models are reported in Table 3. Models I, II, III and IV capture, respectively, indicators including, bank deposits, liquid liabilities, domestic credit to private sector and interest rate spread. It can be observed that irrespective of the financial development indicators used, there exists no long-run relationship between real GDP and its determinants, namely, remittance inflows and financial development indicators as the F-statistic associated with each model is below the lower critical bound $(\mathrm{I}(0))$ at the $10 \%$ significance level.

\begin{tabular}{|c|c|c|c|c|}
\hline & Model I & Model II & Model III & Model IV \\
\hline F-statistic & 1.5783 & 1.8966 & 1.3357 & 1.8352 \\
\hline \multicolumn{5}{|l|}{ Critical values } \\
\hline Significance & \multicolumn{2}{|c|}{$\mathrm{I}(\mathrm{O})$ Bound } & \multicolumn{2}{|c|}{$\mathrm{I}(1)$ Bound } \\
\hline $10 \%$ & \multicolumn{2}{|c|}{2.72} & \multicolumn{2}{|c|}{3.77} \\
\hline $5 \%$ & \multicolumn{2}{|c|}{3.23} & \multicolumn{2}{|c|}{4.35} \\
\hline $2.5 \%$ & \multicolumn{2}{|c|}{3.69} & \multicolumn{2}{|c|}{4.89} \\
\hline $1 \%$ & \multicolumn{2}{|c|}{4.29} & \multicolumn{2}{|c|}{5.61} \\
\hline
\end{tabular}

\subsubsection{The Regression Results}

Having established the absence of a long-run relationship between foreign remittances and economic growth irrespective of the indicators of financial development used, the study focuses mainly on the short-run ARDL estimates (similar to Equation 11 above). Table 4 presents the two-stage least squares estimates of remittancesgrowth nexus for each of the four financial development indicators employed. Irrespective of the financial development indicator used, there is a one-to-one positive association between the current value of real GDP and its previous value, and the autoregressive coefficients in all cases are statistically significant at $1 \%$ level of significance. This implies that the dynamics of determination of real GDP in Nigeria follows adaptive expectation.

Across the four specifications but one, remittance inflows exert negative effects ${ }^{7}$ on real GDP. In Model I, a 1 percentage point increase in remittance inflows tend to generate a decline in real GDP by $4.4 \%$ on average keeping other variables constant. In Model II, remittance inflows have the potential to reduce real GDP by $3.9 \%$, and in Model III, by $5.5 \%$. In the first three specifications, the coefficients on remittance inflows are individually significant at $1 \%$ level of significance. However, in Model IV, 1 percentage point increase in remittance inflows could generate an increase in real GDP by $5.6 \%$ on average keeping other explanatory variables constant. The impact coefficient is however not statistically significant at the $10 \%$ level.

Across the first three specifications, financial development measured by bank deposits, liquid liabilities, and domestic credit to private sector, respectively are found to dampen 8 real GDP growth. Every 1 percentage point increase in bank deposit leads on average to a $1.5 \%$ decline in real GDP keeping other variables constant; liquid liabilities cause a much smaller decline of $0.9 \%$, and domestic credit to private sector leads to a decline in real GDP of $2.7 \%$ on average. These results reflect the shallow nature of Nigeria's financial sector in its financial intermediation role between the surplus (savers) and deficit (investors) units in the economy. However, a 1 percentage point increase in interest rate spread leads to a rise in real GDP by $2.3 \%$ on average keeping other explanatory variables constant. While the impact coefficients on the volume of finance (bank deposits, liquid

${ }^{7}$ This result complements the findings of Barajas, Chami, Fullenkamp, Gapen and Montiel, (2009) but is in contrast to the findings of Odionye and Emerole, (2015).

${ }^{8}$ Result contrasts with the findings of Adelakun (2010). 
liabilities, and domestic credit to private sector) are statistically significant at the $5 \%$ level, the impact coefficient on the efficiency of finance, proxied by the interest rate spread, is significant at $10 \%$ level of significance. This result is counter-intuitive since the expectation is that prospective investors are discouraged from borrowing due to high cost of credit (or higher lending rate). The inefficiency in the financial system is therefore obvious through the increasing gap between lending rate and deposit rate.

Across the first three specifications, remittance inflows relate complementarily with financial development to promote growth, though with an insignificant margin. Remittances impact growth positively and indirectly through bank deposits and liquid liabilities ${ }^{9}$ by a marginal effect of $0.2 \%$, and through domestic credit to private sector by a much higher marginal effect of $0.4 \%$ keeping other variables constant. These impact coefficients are statistically significant at 5 to $10 \%$ level. This result is an indication that domestic credit to private sector has higher growth potential than banks deposits and liquid liabilities, particularly through the investment channel. However, the interaction between remittance inflows and interest rate spread dampens ${ }^{10}$ growth. Remittances impacts growth negatively and indirectly through the interest rate spread by a factor of $0.9 \%$ keeping other explanatory variables constant, though the impact is insignificant at $10 \%$ level of significance. This result is reflective of the substitutability between foreign remittances and financial development in promoting economic growth in Nigeria. ${ }^{11}$

The explanatory power of the four models as measured by the adjusted $\mathrm{R}^{2}$ is very high and ranges between 0.97 and 0.98 . This implies that across the four specifications, about $97 \%$ to $98 \%$ of the total variation in real GDP is being explained by remittance inflows, financial development indicators and interactions between the two variables. Irrespective of specifications, the J-statistics, which test the validity of the instruments, show that the instruments used in this study are valid since the associated probabilities are in excess of 0.1 (that is, $p>0.1$ ). In addition, the endogeneity test conducted on the explanatory variables in all four models suggests the acceptance of the null hypothesis that the explanatory variables in each model are exogenous; hence, the issue of reverse causality has been carefully addressed in this study.

Table-4. Two-stage least square estimates of the nexus between growth and remittances.

\begin{tabular}{|c|c|c|c|c|}
\hline \multicolumn{5}{|c|}{ Dependent variable: $L R G D P_{t}$} \\
\hline Variable & Model I ${ }^{\mathrm{A}}$ & Model II ${ }^{\mathrm{B}}$ & Model III $^{\mathrm{C}}$ & Model IV \\
\hline$L R G D P_{t-1}$ & $1.032 * * *(0.045)$ & $1.005 * * *(0.039)$ & $1.034 * * *(0.049)$ & $1.015 * * *(0.049)$ \\
\hline$R E M I T_{t}$ & $-0.044 *(0.023)$ & $-0.039 *(0.021)$ & $-0.055^{*}(0.029)$ & $0.056(0.037)$ \\
\hline DEPOSIT $_{\boldsymbol{t}}$ & $-0.015^{* *}(0.007)$ & & & \\
\hline$R E M I T_{t} * D E P O S I T_{t}$ & $0.002 * *(0.001)$ & & & \\
\hline$L L T_{t}$ & & $-0.009 * *(0.004)$ & & \\
\hline$R E M I T_{t} * L L T_{t}$ & & $0.002 *(0.001)$ & & \\
\hline$P C R_{t}$ & & & $-0.027 *(0.012)$ & \\
\hline$R E M I T_{t} * P C R_{t}$ & & & $0.004 * *(0.002)$ & \\
\hline$S P R E A D_{t}$ & & & & $0.023 *(0.012)$ \\
\hline$R E M I T_{t} * S P R E A D_{t}$ & & & & $-0.009(0.006)$ \\
\hline$C$ & $-0.534(1.141)$ & $0.145(1.021)$ & $-0.472(1.245)$ & $-0.453(1.265)$ \\
\hline Adjusted $R^{2}$ & 0.9761 & 0.9791 & 0.9672 & 0.9729 \\
\hline F-statistic & $325.43[0.0000]$ & $372.45[0.0000]$ & $238.03[0.0000]$ & $286.78[0.0000]$ \\
\hline J-statistic & $1.6946[0.4286]$ & $2.3202[0.3135]$ & $0.1753[0.9161]$ & $1.7045[0.4265]$ \\
\hline Endogeneity test & $4.2006[0.3795]$ & $3.1807[0.5280]$ & $6.4794[0.1661]$ & $4.8028[0.3081]$ \\
\hline List of instruments & \multicolumn{4}{|c|}{$\begin{array}{l}C, L R G D P_{t-2}, R E M I T_{t-1}, D E P O S I T_{t-1}, L L T_{t-1}, P C R_{t-1}, S P R E A D_{t-1} \\
G C O N S_{t-1}, G F C F_{t-1}, T O P_{t-1}\end{array}$} \\
\hline
\end{tabular}

Note: ****,**, and * indicate the rejection of the null hypothesis of no relationship and/or association at $1 \%, 5 \%$ and $10 \%$ respectively; imply that the four models capture, respectively, bank deposits, liquid liabilities, domestic credit to private sector, and interest rate spread as the indicators of financial development.

\section{Conclusion}

Motivated by the unsettled debate in the literature concerning the role of financial sector in the nexus between foreign remittances and economic growth, the present study has analyzed the complementarity or substitutability between remittances and financial development in advancing Nigeria's economic growth between 1981 and 2015. To circumvent the possible endogeneity problem among remittances, financial development and growth, the twostage least squares (2SLS) technique was employed. Across the specifications considered, findings showed the absence of a long-run relationship between foreign remittances and growth having properly accounted for the role of financial sector development. Across specifications, foreign remittance inflows had negative and significant effect on economic growth with financial development indicators including bank deposits, liquid liabilities and domestic credit to private sector being accounted for, whereas it had positive effect on growth when interest rate spread is controlled for as the financial development indicator.

Mixed results were generated concerning the growth effects of financial development indicators used in this study: while the indicators that measure the volume of finance were growth dampening, the efficiency indicator was found to be growth enhancing. In addition, in contrast to previous findings, this study offered new evidence that the complementarity or substitutability between remittances and financial development in economic growth depends on the indicators of financial development used. In other words, the complementarity hypothesis was confirmed in the case of the quantitative indicators (that is, bank deposits, liquid liabilities and domestic credit to

${ }^{9}$ Result parallels the findings of previous studies including, Mundaca (2009), Bettin and Zazzaro, (2011), Nyamongo, Misati, Kipyegon and Ndirangu, (2012), Chia (2014) and El Hama (2016).

${ }^{10}$ Result confirms the previous findings of Ramirez and Sharma, (2008), Giuliano and Ruiz-Arranz, (2009) and Tung (2015).

${ }^{11}$ According to Bettin and Zazzaro, (2011) the negative interactive effect of remittances and interest rate spread captures the diminishing marginal impact of financial sector size on economic growth. 
private sector), while the substitutability hypothesis was validated in the case of the qualitative measure of financial sector development (that is, interest rate spread).

Based on these findings, it is important that the Nigerian government considers the following action points. First, interest rate spread should be kept very low so as to boost the efficiency of the domestic financial sector. This would in turn reduce the cost of borrowing and stimulate private investment. Secondly, the deposit-money banks need to allocate enough funds to the real productive sectors in the economy in a bid to stimulate output growth. ${ }^{12}$ Lastly, both migrant workers and their beneficiaries should be encouraged to make use of banks so that remittances could be made available to finance genuine investment projects. This could be achieved possibly through boosting the confidence of migrant workers in the financial system and by raising the deposit rate so as to entice the beneficiaries to save a large portion of remittances received.

\section{References}

Adelakun, O., 2010. Financial sector development and economic growth in Nigeria. International Journal of Economic Development Research and Investment, 1(1): 25-41.

Adeniyi, O., A. Oyinlola, O. Omisakin and F.O. Egwaikhide, 2015. Financial development and economic growth in Nigeria: Evidence from threshold modelling. Economic Analysis and Policy, 47: 11-21.Available at: https://doi.org/10.1016/j.eap.2015.06.003.

Agbélénko, F.A. and K.S. Kibet, 2015. Financial development and economic growth in West African Economic and Monetary Union (WAEMU). African Journal of Business Management, 9(17): 624-632.

Aggarwal, R., A. Demirgüç-Kunt and M.S.M. Pería, 2011. Do remittances promote financial development? Journal of Development Economics, 96(2): 255-264.

Ahortor, C.R.K. and D.E. Adenutsi, 2009. The impact of remittances on economic growth in small-open economies. Journal of Applied Sciences, 9(18): 3275-3286.Available at: https://doi.org/10.3923/jas.2009.3275.3286.

Akkoyunlu, S., 2013. Remittances and financial development: Is there a direct link? Evidence from Turkish Data. Available from https://www.researchgate.net/publication/256498527.

Allen, D.S. and L. Ndikumana, 1998. Financial intermediation and economic growth in South Africa. The Federal Reserve of St. Louis Working Paper Series no. 1998-004B.

Asteriou, D. and S.G. Hall, 2007. Applied econometrics: A modern approach. Revised Edn., Hampshire, New York: Palgrave Macmillan.

Balago, G.S., 2014. Financial sector development and economic growth in Nigeria: An empirical investigation. International Journal of Finance and Accounting, 3(4): 253-265.

Barajas, A., R. Chami, C. Fullenkamp, M. Gapen and P. Montiel, 2009. Do workers' remittances promote Economic growth?” International Monetary Fund (IMF) Working Paper No. WP/09/153.

Barguellil, A. and M.E.H. Zaiem, 2013. The effect of migrant remittances on economic growth through education: The Case of Tunisia. International Journal of Economics and Management Sciences, 2(8): 33-40.

Beck, T., A. Demirguc-Kunt, R.E. Levine, M. Cihak and E.H.B. Feyen, 2015. Financial development and structure data set (updated september, 2015). Available from www.worldbank.org/en/publication/gfdr/data/financial-structure-database.

Bettin, G. and A. Zazzaro, 2011. Remittances and financial development: Substitutes or complements in economic growth? Bulletin of Economic Research, 64(4): 509-536.

Catrinescu, N., M. Leon-Ledesma, M. Piracha and B. Quillin, 2009. Remittances, institutions, and economic growth. World Development, 37(1): 81-92.

Chenery, H. and A. Strout, 1966. Foreign assistance and economic development. American Economic Review, 56(4): 679-733.

Chia, Y.E., 2014. Remittances, financial depth and economic growth of Malaysia. Labuan Bulletin of International Business and Finance, 12: 48-60.

Chowdhury, M.B., 2011. Remittances flow and financial development in Bangladesh. Economic Modelling, 28(6): 2600-2608.

Dandume, M.Y., 2014. Financial sector development, economic growth and poverty reduction: New evidence from Nigeria. Karaankırı KaratekinUniversity Journal of the Faculty of Economics and Administrative Sciences, 4(2): 1-20.

Dickey, D.A. and W.A. Fuller, 1979. Distribution of the estimators for autoregressive time series with a unit root. Journal of the American Statistical Association, 74(366): 427-431.

El Hama, I., 2016. Linking remittances with financial development and institutions: A study from selected MENA countries. Groupe de recherché en Droit, Economie et Gestion (GREDEG) Working Paper Series No. 2016-38.

Fayissa, B. and C. Nsiah, 2010. The impact of remittances on economic growth and development in Africa. The American Economist, $55(2)$ : 92-103

Giuliano, P. and M. Ruiz-Arranz, 2009. Remittances, financial development, and growth. Journal of Development Economics, 90(1): 144-152. Gujarati, D.N. and D.C. Porter, 2009. Basic econometrics. New York, USA: Published by McGraw-Hill Irwin.

Ikeora, J.J., M.N. Igbodika and P.W. Andabai, 2016. Banking sector reforms and the performance of Nigerian economy: A vector error correction investigation (VECM). European Journal of Research and Reflection in Management Sciences, 4(2): 52-59.

Jongawanich, J., 2007. Workers' remittances, economic growth and poverty in developing Asia and the pacific countries. United Nations Economic and Social Commission for Asia and the Pacific (UNESCAP) Working Paper No. WP/07/01.

Kayode, O. and J. Adeleye, 2016. International remittance inflows and banking sector development in Nigeria. IOSR Journal of Economics and Finance, 7(3): 1-8.

Lucas, R.E., 1988. On the mechanics of economic development. Journal of Monetary Economics, 22: 3-42.

Meyer, D. and A. Shera, 2017. The impact of remittances on economic growth: An econometric model. EconomiA, 18(2): 147-155.Available at: https://doi.org/10.1016/j.econ.2016.06.001.

Motelle, S.I., 2011. The role of remittances in financial development in Lesotho: Evidence from alternative measures of financial development. Journal of Development and Agricultural Economics, 3(6): 241-251.

Mundaca, B.G., 2009. Remittances, financial market development, economic growth: The case of Latin America and the Caribbean. Review of Development Economics, 13(2): 288-303.

Nyamongo, E.M., R.N. Misati, L. Kipyegon and L. Ndirangu, 2012. Remittances, financial development and economic growth in Africa. Journal of Economics and Business, 64(3): 240-260.

Odionye, J.C. and O.B. Emerole, 2015. The impact of international remittances on the Nigerian economy. British Journal of Economics, Management \& Trade, 7(1): 1-9.Available at: https://doi.org/10.9734/bjemt/2015/13290.

Ogujiuba, K. and M.E. Obiechina, 2011. Financial sector reforms in Nigeria: Issues and challenges. International Journal of Business and Management, 6(6): 222-233.

Ogwumike, F.O. and A.A. Salisu, 2012. Financial development and economic growth in Nigeria. Journal of Monetary and Economic Integration, 12(2): 91-119.

Ojapinwa, T.V. and O.T. Bashorun, 2014. Do workers' remittances promote financial development in Sub-Sahara Africa countries. International Journal of Financial Research, 5(2): 151-159.Available at: https://doi.org/10.5430/ijfr.v5n2p151.

Oke, B.O., 2011 . Impact of workers' remittances on financial development in Nigeria. International Business Research, 4(4): $218-225$.

Oyinlola, M.A. and A. Adedeji, 2017. Human capital, Financial sector development and Inclusive growth in sub-Saharan Africa. Economic Change Restructing.

Pesaran, M.H., Y. Shin and R.J. Smith, 2001. Bounds testing approaches to the analysis of level relationships. Journal of Applied Econometrics, 16(3): 289-326.Available at: https://doi.org/10.1002/jae.616. 
Phillips, P.C. and P. Perron, 1988. Testing for a unit root in time series regression. Biometrika, 75(2): 335-346.Available at: https://doi.org/10.1093/biomet/75.2.335.

Ramirez, M.D. and H. Sharma, 2008. Remittances and growth in Latin America: A panel unit root and panel cointegration analysis. Yale University Economics Department Working Paper No. 51.

Romer, P.M., 1986. Increasing returns and long-run growth. Journal of Political Economy, 94(5): 1002-1037.Available at: https://doi.org/10.1086/261420.

Shahzad, S.J.H., N. Adnan, A. Sajid and R. Naveed, 2014. Impact of remittances on financial development In South Asia. Review of Economic and Business Studies, 7(2): 11-29.

Solow, R.M., 1956. A contribution to the theory of economic growth. The Quarterly Journal of Economics, 70(1): 65-94.

Tung, D.T., 2015. Remittances and economic growth in Vietnam: An ARDL bounds testing approach. Review of Business and Economic Studies, 3(1): 80-88.

Umejiaku, R.I., 2011. Financial reform and financial development in Nigeria: A graphical analysis. African Research Review, 5(3): 247260.Available at: https://doi.org/10.4314/afrrev.v5i3.67355.

Vargas-Silva, C., S. Jha and G. Sugiyarto, 2009. Remittances in Asia: Implications for the fight against poverty and the pursuit of Economic growth. Asian Development Bank (ADB) Working Paper Series No. 182.

Word Development Indicators (WDI), 2017. Database of the World Bank. Available from https://data.worldbank.org/country/nigeria. 